\title{
The Need For a Contemporary Nigerian Philosophy to be Taught at Every Level of Nigeria's Educational Programme
}

\author{
Emmanuel Kelechi Iwuagwu, PhD \\ Department of Philosophy, University of Calabar - Nigeria
}

doi: 10.19044/esj.2016.v12n26p249 URL:http://dx.doi.org/10.19044/esj.2016.v12n26p249

\begin{abstract}
This paper while acknowledging the importance of an in-depth study of Western philosophy as well as African philosophy for students of philosophy department holds that this content will not bring about the ethical, socio-political and economic reengineering very much needed in Nigeria. It is the contention of this paper that there is great need for social value reorientation in Nigeria and philosophy should provide the hub for this reengineering of the Nigerian society. The paper argues that there is a big vacuum at the base of Nigeria's educational system where the students lack any philosophical sense of direction and do not as much as know the philosophy that underlies the societal way of life. The paper employing a critical philosophical appraisal of the current state of affairs argues that philosophy should not only be merely introduced to university students as one of the general courses studied for one semester, it should be studied from the nursery/primary school level through the secondary school to the university level. The content according to this paper should be well articulated as Contemporary Nigerian Philosophy with emphasis on moral leadership training with focus to incorporate future leaders into national values as well as inculcate in them a sense of patriotism which will help address the current ethical, socio-political and economic problems confronting the present day Nigerian society. The paper concluded by advocating the philosophical formulation of a generally acceptable value design to be copied by every segment of the society which will be taught as Contemporary Nigerian Philosophy at all levels of the Nigerian educational program and for all students whether in public or private schools.
\end{abstract}

Keywords: Contemporary Nigerian Philosophy, Educational Program, Socioethical values, Social change, Socio-ethical re-orientation 


\section{Introduction}

Every individual or society operates by a particular philosophy of life even when they are not conscious of it. The behavior of every person is inspired by a certain philosophical perspective which colours his vision of reality and propels his values and responses to the events, problem and challenges of his world.

The contemporary Nigerian is torn between the traditional African value system and the foreign European/American values system that makes him half African and half European and consequently neither African nor European. In the era of globalization the present day Nigerian stands stranded, bemused and apparently confused by myriads of influences and values that daily confront him in every facet of life. The contemporary Nigerian, child, youth or adult is inundated by foreign values emanating from foreign cultures, ideologies and philosophies. As a consequence of this, the rich traditional African values which are products of African thought and culture are gradually evaporating, thereby leaving the contemporary Nigerian without any philosophical identity different from that of the European or American.

This apparent crisis of philosophical identity and the urgent need to redefine the philosophical undertone that should form the basis of contemporary Nigerian thought and action is the motivating force behind this paper, hence the paper raises the question of the philosophy that should be behind the contemporary Nigerian private and public life; the philosophy that should guide his moral life in the society, his economic life, his social life, the country's foreign policy, the individual's political life etc. It is the contention of this paper that without a properly defined philosophical outlook to guide Nigerians, the society cannot but lack a sense of direction because of multiple unacceptable philosophies widely promoted. This will cause the country's internal and foreign policies to lack a philosophical base.

This paper employing expository and critical methods with regards to the existing situation and the consequent problems, frowns at the philosophical lacuna at the base of Nigerian educational programme as well as the poor and inadequate content of the kind of philosophy that is introduced to the Nigerian students at the university level in the GSS course called Philosophy and Logic. This lacuna at the end leaves the students deprived of any meaningful orientation in the core values that will instill in them patriotism in nation building.

The paper exposing and deploring this vacuum caused by the absence or inadequate content of philosophical orientation among Nigerian students proposes that a well-articulated Nigerian contemporary philosophy which will be formulated from the traditional African philosophy and Western philosophy as presently constituted should be brought on board to propel 
social value orientation very much needed to bring about ethical, sociopolitical and economic re-engineering of the present day Nigerian society.

The contemporary Nigerian philosophy so proposed, according to the paper, should inculcate in the young moral probity and a sense of patriotism in working for national interest and the common good rather than selfish interest. In other that the proposed philosophy have the much expected impact of re-engineering the social value design of the contemporary Nigerian society, the paper recommends that it be taught at every level of Nigerian educational program namely: the nursery/primary school level, the secondary school and at the tertiary levels.

The paper concluded that when the above proposals are bought and implemented, future Nigerian leaders of thought (the youth) will be incorporated into national values, become patriotic, be inspired to work for the common good and be able to address and defeat the current ethical, sociopolitical and economic challenges confronting the contemporary Nigerian society.

\section{Philosophy as a Tool of Social Change}

The history of civilization is replete with the substantial contributions made by philosophers in advancing positive social change. The impact of classical philosophical schools of thought to the development of the ancient world is great. Philosophical systems and theories like Idealism, Realism, Rationalism, Stoicism, Epicureanism, etc., were very influential in ancient times in shaping peoples way of life in the ancient world. Likewise in the medieval, modern and contemporary era philosophical systems like empiricism, positivism, phenomenalism, pragmatism, existentialism etc., were very instrumental in shaping the face of the society through individual behaviours.

Philosophical theories in the ethical, socio-political, economic and other diverse areas of study have also advanced individual moral behavior and better systems of government which safeguarded freedom and human rights, peace and security in the human society as well as economic progress and wellbeing. Thus philosophy has contributed immensely in propounding theories which has helped in organizing the human society in the best possible way that can help its members to actualize their potentialities. It can be emphatically said that Western civilization is a beneficiary of the philosophical theories propounded by philosophers which guided them through the course of their history and which account for their development. Without philosophers and their theories which guides practice, the human society would have remained stagnant and the human condition unbearable.

According to Omoregbe $(2007, \mathrm{x})$, "Philosophical ideas are dynamites which can explode, shatter things and bring about a radical transformation of 
structures". From the foregoing it becomes a challenge to philosophers of all ages to put forward philosophical ideas that will positively change the face of their society, philosophies that will guide policies and practice, that will guide the moral behavior of individuals as well as influence public life. The position that education is a potent tool for socio-political and economic development is supported by the foremost Nigerian philosophers of education Nnamdi Azikiwe, Awolowo and Jubril Aminu. (Owan, Enoh A, 1996, 356-357)

It is not out of place therefore that in the face of the current ethical, socio-political and economic challenges facing Nigeria, contemporary philosophers should step in and take the bulls by the horns and bail the country out of these pressing problems. Moral, socio-political and economic theories should be propounded and practiced to provide guidance out of the disturbing and unbearable situation the country is experiencing.

\section{The Philosophical Lacuna at the Lower Level of Nigeria's Educational Programme}

It is a fact that a greater percentage of Nigerian students come in contact with the study of philosophy for the first time in the university when they were already $70 \%$ formed. Whereas courses like English language, vernacular, mathematics, social studies, history, geography, agriculture etc. are introduced at the nursery/primary school level and other courses like physics, chemistry, economics, biology, government, commerce etc. are included at the secondary school level there is no mention of philosophy until at the university level.

The absence of this indispensable tool of correct reasoning and social change at the foundation of learning leaves a very huge vacuum in the academic, social and moral life of every student and leaves the student an imbalanced personality. Philosophical ideas are like theory that guides practice without which practice is blind and ineffective.

A cursory look at the course content of the nursery/primary school curriculum reveals the following subjects being taught: Mathematics, English language, Religious Knowledge, Health Education, Elementary Science, Agricultural Science, Social Studies, Computer Science, Fine Art, French, Handwriting, Home Economics, Verbal Reasoning, Quantitative Reasoning, Phonics and Physical Education. At the secondary school level more courses are added with most of those done in primary school retained. Thus we have the following subjects in secondary school curriculum both for cognitive and psychomotor assessment: Mathematics, English Language, Integrated Science, Business Studies, Practical Agriculture, Social Studies, Home Economic, Physical and Health Education, Christian Religious Studies, Local Craft, Tourism, Civics Education, Drawing, Sport, Music, Physics, Chemistry, Biology, Geography, Fine Art, Literature in English, Commerce, Economics, 
Government, History, Introtech, French, Efik, ICT, Marketing, Food/Nutrition, Further Mathematics etc. (Ministry of Education, Students' Terminal Report Sheet).

From the above listed subjects we observe a lacuna, the absence of philosophy which is a catalyst of social change, the course that introduces correct and critical reasoning, which inculcates the ethical and social values for the formation of character, a course which provides the underlying structure of the peoples' worldview and guides private life and public policy. Education according Schofield $(1981,204)$ "is a medium thorough which society transmits what it finds valuable, the content of education can be defined as a set of values. Hence in examining the curriculum, the content of that formal education which the school acting on behalf of society, transmits, we are involved in a decision of what is valuable, with norms or standards." We can therefore say that the absence of philosophy leaves the entire school curriculum at the lower level of education grossly inadequate and in urgent need of updating.

\section{The Philosophy Studied at the Tertiary Institution Level.}

It is sad to observe that philosophy is only studied at the universities alone. The polytechnics, monotechnics, colleges of education and other higher institutions do not study philosophy and logic as it is called in the universities (colleges of education do study philosophy of Education only). Thus those who do not have the opportunity of studying in the universities may never come across the study of philosophy. Of greater concern is the course content of the philosophy introduced to Nigerian students in the universities and their relevance to the promotion of nation building through proper social and moral value re-orientation.

In the first instance except in the philosophy departments of the universities, philosophy and logic is studied only as a GSS course for one academic semester. During this study after introducing the subject matter of philosophy, its branches, systems and methods, the history of Western philosophy ancient, medieval, modern and contemporary eras are studied before a brief overview of African philosophy. On the part of logic, the study covers the subject matter of logic, the laws of thought, arguments (their types and evaluation), fallacies, definitions, propositions and inferences, logical operators, truth tables, formal proofs etc.

In as much as the course content is rich, its relevance to social value re-orientation that can propel ethical, socio-political and economic reengineering of the nation is not clearly seen nor felt. The study of Western philosophy may provide a historical relevance of learning from history to avoid the mistakes of the past and to learn from the successes of the past, but 
designing a philosophy to address present day problems is an urgent challenge to contemporary philosophy.

The very little or no space given to inculcating African values, morality, national consciousness and the supremacy of the common good is worrisome and leaves so much to be desired with regard to the formation given to the generality of Nigerian students.

As for the philosophy studied in the philosophy departments, in addition to the many core philosophical courses like metaphysics, logic, epistemology, ethics, social and political philosophy, aesthetics, philosophy of science, philosophy of religion, history of philosophy, analytic philosophy etc. many courses that will be a tool of social change and national re-orientation are offered, these include; philosophy of culture, applied ethics, leadership philosophies and decision theories, philosophy and gender issues, philosophy of environment, African philosophy and values, professional ethics, philosophy of peace and conflict resolution, philosophy of economic and social development, philosophy of education, philosophy of law etc. (UNICAL Dept. of Philosophy Handbook, 2014, 11-13). These courses are not taught at the GSS course Philosophy and Logic which the generality of university students study for one semester. They are not also taught at the primary or the secondary school levels of education confirming the lacuna at the base of learning.

It must be observed with concern and worry also that even in some philosophy departments of the universities, some of these courses which are very relevant to social orientation and national development are made optional courses whereas other courses on Western philosophy are made compulsory, thereby downgrading the relevance of the former.

From the foregoing, it is clear that the only philosophy which an average Nigerian student is exposed to leaves so much to be desired with regard to proper philosophical orientation that will inculcate socio-ethical values and national consciousness in future leaders. The brevity of the course duration - one semester also offers little room for an enriched course content to bring about social re-engineering of a decadent society.

\section{The Decadent State of Nigeria's Ethical, Socio-Political and Economic Situation in Urgent Need of Rescue}

The Nigerian state over the years have sailed like a troubled and sinking ship on a turbulent sea being tossed up and down in sight of no shore to anchor. Nigerians to mitigate the heightened tension in such a sinking ship have adopted the posture of suffering and smiling, praying and hoping that the ship will one day anchor and offer them some respite. For many years Nigeria has been seen by many critical observers as a collapsed state which though not in a state of war is a nursery bed for impunity and lawlessness. The situation 
of the country paints a picture of a jingle state where everything goes, where the highly placed individuals and organizations can commit any crimes and go scot free; where plundering and looting of the public wealth is allowed and even considered a blessing and the life of its citizens are worthless and the destruction of it inconsequential.

Among the myriads of problems confronting the present day Nigerian society include; insecurity of life and property perpetuated by terrorist groups and freedom fighters like the Boko Haram, Niger Delta Militants, MASSOB, IPOB, OPC(Odua People Congress), kidnappers, armed robbers and advanced fee fraudsters(419); collapsed infrastructures raging from bad roads, poor health care provision, epileptic power supply; insufficient petroleum products for domestic use resulting in long queues at petrol stations; poor educational facilities; fragrant disregard for the rule of law; electoral malpractices; corruption in all quarters; sabotage of the common good; juvenile delinquency; collapse of the integrity of the social institutions (like the Judiciary, the legislature, traditional institutions etc.) and general economic hardships.

Over the years the average Nigerian knows that all is not well with the country, there is the clamour for a messiah who will liberate the country from these woes. Some have called for a revolution from the masses since the elites have failed to salvage the situation through various forms of governments, military, multi-party democracy, two-party democracy etc.

The Nigerian ethical, socio-political and economic problems are discussed everywhere and by Nigerians of all age brackets, the lamentation appears unending and has been blamed on bad leadership (Achebe, 1983, 1), on corruption (Ochulor, 2010, 466), on ambivalence of human interest (Asouzu, 2003, 20), on the overabundance of human and natural resources and on the resilient (over tolerable) spirit of Nigerians.

Whatever the reasons there may be for the apparent stagnation of the Nigerian state when compared with the Asian Tigers (Hong Kong, Singapore, Taiwan and South Korea) who were once on the same parity with Nigeria, there is urgent need for a bailout, for an ethical, socio-political and economic re-engineering of the state. There is the need for a total re-orientation and value design to redirect the Nigerian ship that appears to be making an unending voyage in the wrong direction.

If ideas change the world, and philosophical ideas are catalyst of social positive change, the time has come therefore for Nigerian philosophers to provide the hub for this social re-engineering, to articulate urgently the philosophical theories that will keep afloat the sinking Nigerian state. The time for philosophers to salvage the situation is at hand and this must be done through sound educational program at all levels. 


\section{The Need for a Contemporary Nigerian Philosophy}

It is said that necessity is the mother of invention. Adversity generates ideas. The collapse of the Greek city states and Alexandrian empires in the ancient times and its attendant depressing social environment arising from the breakdown of social order led to the formulations of philosophies like Cynicism, Stoicism, Epicureanism, Hedonism, Skepticism etc. (Uduigwomen, 2006, 35). Nicola Machiavelli, Thomas Hobbes, Jean Jacques Rousseau and John Locke were inspired to propound their political theories because of the socio-political climate of their time marked by insecurity, devastation and anarchy (Nisbet, 1983, 24-29) The situation of general hardship during these times inspired philosophers to formulate philosophies of how men should respond to these adverse situations and achieve peace, security and general wellbeing for the people.

The current Nigerian situation demands urgent attention and it is time for philosophers to rise up to the challenge and articulate a sound philosophical roadmap that can redirect the depressing situation to a brighter prospect.

The argument that there are already on ground many philosophies that Nigeria should adopt will collapse when one considers the peculiarity of Nigeria, its diverse socio-cultural background, history and orientation. It must also be acknowledged that some philosophical theories are limited by time, location and situation; hence they may be effective at a particular period, place and situation but be ineffective at another.

If we agree that the Nigerian problem is principally caused by bad leadership, corruption and unpatriotic behaviours, then what Nigeria needs is a total re-orientation, a total re-designing of the social values that can bring about a moral revolution and inculcate a culture of hard work for the common good, patriotism, spirit of self-sacrifice, and dedication to duty. The American philosophical identity is Pragmatism. This guides the life of an average American and is the philosophy that underlines their national and foreign policies. Nigeria needs a philosophical identity to guide private and public life.

The Nigerian nation needs a total overhauling and philosophy should provide the hub for this re-engineering, philosophy must stand out and lead the way out of this ethical, socio-political and economic quagmire. Philosophers must articulate ethical theories peculiar to Nigeria from our rich traditional values. They must propound socio-political and economic theories that should address the many ironies and paradoxes in the Nigerian society which have defied foreign solutions that have worked elsewhere. Philosophers must articulate a philosophy that can forge a patriotic spirit of nationalism from multiple ethnic groups that constitute the Nigerian state, one that promote Nigerian nationality above ethnic nationality. (Iwuagwu, 2015, 178) 
There is need for a philosophy that will inculcate in all the sanctity of the common good which must be promoted and respected by all. Nigeria needs a philosophy that will create servant leaders at all segments of the social strata. A philosophy that will raise servant leaders who will be hungry to leave legacies wherever they work and not looters who will only be proud of what they acquired for themselves while in office. The country needs a philosophy which will breed men and women of integrity who can raise their heads high in and outside Nigeria and who will be transparent and be ready to be probed after service and not people who will rush to get court injunctions to prevent their being investigated or prosecuted.

The philosophy to be articulated should inculcate in the young the spirit of hard work and the pride of displaying the fruits of an honest hard work and the shame of holding the proceeds of corruption. A philosophy that will eradicate the sense of impunity that is currently going unchallenged and be able to create a sense of shame and remorse in times of wrong doing. One that will quell excessive quest for illicit wealth, question illicit wealth, breed accountability and restore the integrity of the social institutions.

\section{The Bedrock of the Proposed Contemporary Nigerian Philosophy}

Before the advent of European civilization and influence the various ethnic nationalities that constitute the Nigerian federation have traditional values, customs and laws that guide the social behavior of its members. These rich socio-ethical values are transmitted to the young through folklores, stories, proverbs, poems, songs and examples. With the coming of Western education and influence these values, customs, traditions and laws were abandoned creating a very big vacuum. The replacement of African values with Western values appeared like putting a square peg in a round hole creating some social imbalance arising from a crisis of identity. To correct this anomaly which grossly affected the socio-political and economic progress of Nigeria, the contemporary philosophy to be formulated must have recourse to the rich socio-ethical values of the traditional African societies. Such traditional socio-ethical mores, customs and values must constitute the bedrock of such philosophy to enable it achieve the moral revolution very much needed in re-engineering the socio-political and economic structure of the Nigerian state.

The absence of a sound socio-ethical foundation bearing the Nigerian structure makes the whole edifice shaky and in imminent danger of collapse, just like a gigantic building without a solid foundation. The socio-ethical African values that must constitute the basis of contemporary Nigerian philosophy should include; the sacredness of human life, promotion of and respect for common good, respect for elders and constituted authority, hard work, honesty, patience, patriotism, love of integrity, accountability, probity 
and the spirit of communalism and solidarity. These socio-ethical values are echoed in various forms in traditional folklores, proverbs, songs, poems, stories, customs and beliefs. They were very potent tools of socio-ethical orientation for the young in many traditional African societies. According to Fafunwa (1971, 21), "Indigenous African education places emphasis on character-training. Indeed it is the cornerstone of African education" What the philosopher needs now is to formulate a philosophy that will incorporate these values and design an acceptable programme for their transmission to the young for character formation.

The proposed philosophy should not exclude the contents of Western philosophy as taught in the philosophy departments of the universities which are mentioned above, it should incorporate those courses in Western philosophy which will stimulate positive social change and proper national orientation. Among such courses should include leadership philosophies and decision theories, philosophy of peace and conflict resolution, philosophy of economic and social development, philosophy of education, philosophy of environment etc. A mixture of these and many progressive philosophies like Pragmatism will enhance the realization of the much needed ethical, sociopolitical and economic advancement of Nigeria.

\section{The Transmission of Contemporary Nigerian Philosophy at the Various Stages of Nigerian Educational Programme.}

As it was noted above, there is a very big philosophical lacuna at the basis of Nigerian educational programme where there is no mention of philosophy until at the university level when the young people have already being deformed by wrong ideologies and influences. If the proposed contemporary Nigerian philosophy is to be widespread and serve as a potent tool to revolutionize the psyche of an average Nigerian, it must be transmitted through the educational institutions at all levels.

The slogan "Catch them Young" comes to mind at this instance. The minds of children are more impressionable thus any wisdom imparted to children become a way of life and like a habit becomes difficult to part with. Hence children and youths who are in nursery/primary schools, secondary schools and the tertiary institutions should be the target group for the proper transmission of this contemporary Nigerian philosophy. If the wisdom and values echoed by this philosophy is inculcated in children and youths, it will lay a very solid foundation for proper socio-ethical behavior which will in turn make them patriotic citizens always ready to promote the common good and work for socio-political and economic development of the country.

It is time, therefore, to include philosophy into the education curriculum of nursery/primary school, secondary school and tertiary institutions in Nigeria. Many Ministries, Departments and Agencies (MDAs) 
have in alliance with the National Educational Resources Center (NERC) introduced into the Nigerian curriculum some very important subjects which were not previously there but which are considered very relevant to national development, such courses include; Entrepreneurship, Computer training, Citizenship Education, Tourism etc.

Very recently, the Central Bank of Nigeria (CBN) announced it has commenced discussion with NERC to introduce financial literacy programs into the education curriculum of secondary schools in Nigeria which will enable financial literacy to be taught as a subject before the end of 2016 . According to the CBN Director, Consumer Protection Department Hajiya Umma Dutse, "At the CBN, we are partnering with numerous agencies to teach our children and youths about financial matters and also to create an enabling environment for them to gain access to basic banking and financial products and services through various initiatives, especially the financial inclusion strategy...the wisdom is that, a habit imparted in youth at an impressionable age becomes a way of life" (Punch Newspaper14/03/2016).

The Nigerian Philosophical Association, the Nigerian Association of Philosophy Students, the Nigerian Union of Teachers, the Faculties and Institutes of Education at the Universities and other stakeholders in the qualitative and pragmatic education enterprise should mount sustained pressure on the National Education Resource Centre and the Federal and State Ministries of Education to include Philosophy in the education curriculum of the Nursery/Primary schools, Secondary and Tertiary Institutions in Nigeria. This inclusion will aid the transmission of not only knowledge but wisdom to the future leaders of our society.

With this wisdom diluted to the capability and comprehension of students at all levels and put in songs, poems, dramas, stories, folklores and other forms of literature (with the aim of character formation and transmission, of socio-ethical values) even those who in future may not have the privilege of tertiary education will surely benefit from the study as they benefit from the study of mathematics and English language for commerce.

\section{Conclusion}

The decadent Nigerian situation demands an urgent solution. This solution should not be at the surface but must be deep-rooted and comprehensive. For a total overhauling of the Nigerian state the appropriate philosophical ideas and theories particular to the Nigerian situation must be formulated and employed to be a catalyst to positive ethical, socio-political and economic change. Education is a tool of social change capable of effecting individual, socio-political and economic emancipation. This means that when the programmes that constitute a nation's educational structure is defective the nation suffers. As this paper has revealed, there is a very big lacuna at the basis 
of Nigerian educational programme which is the absence of the driver of social change - philosophy.

It is the submission of this paper, therefore, that Nigeria needs a total re-engineering to get things right and philosophy must provide the hub for this total value re-orientation. A contemporary Nigerian philosophy drawn from the very rich African cultural and socio-ethical values and the well tested philosophical theories of Western philosophy should be articulated and transmitted to children and youths from the beginning to the end of their educational programme. This will enable these young people whose minds are very impressionable to imbibe the values that can promote national development.

This paper, therefore, recommends that the National Education Research Center (NERC) should introduce philosophy into the education curriculum of the nursery/primary schools, secondary schools and tertiary institutions in Nigeria.

\section{References:}

Achebe, C. (1983). The Trouble with Nigeria. Enugu: Fourth Dimension Publishers.

Asouzu, Innocent I. (2003). Effective Leadership and the Ambivalence Human Interest: The Nigerian Paradox in a

Complementary Perspective.Calabar: University of Calabar Press.

Fafunwa, Babs A. (1971). History of Education in Nigeria. Ibadan: Macmillan Company.

Department of Philosophy, University of Calabar, Handbook. 2014 Iwuagwu, Emmanuel K. (2015). The Concept of Citizenship: Its Application and Denial in the Contemporary Nigerian Society.

International Journal of Research in Arts and Social Science. 2015 Vol. 8 (1) PP. 170-183

Ministry of Education, Calabar, Cross River State, Computerized Students' Terminal Report sheet

Nisbet, Robert (1983). The Social Philosophers. New York: Washington Square Press.

Ochulor,Chinenye Leo andBassey Edet Patrick (2010).Analysis of Corruption From the Ethical and Moral Perspective. European Journal of Scientific Research Vol. 44 No. 3 (2010) PP. 466-476

Omoregebe, J. (2007). Socio-Political Philosophy and International Relations. Lagos: Joja Educational Research and Publishers.

Owan, Enoh A. (1996). Main Current in Nigerian Educational Thought. Jos: Midland Press.

Schofield, Harry (1981). The Philosophy of Education: An Introduction. London: George Allen Unwin. 
The Punch Newspaper. (14/0302016). CBN to Introduce Financial Literary into School Curriculum. www.punching.com/cbn-introduce-financialliterary-school-curriculum.

Uduigwomen, Andrew F. (2006). Introducing Ethics: Trends, Problems and Perspectives. Calabar: Campus Life Arts. 